\title{
INFLUENCE OF CERAMIC WASTE AGGREGATE PROPERTIES ON STRENGTH OF CERAMIC WASTE AGGREGATE CONCRETE
}

\author{
V. Giridhar ${ }^{1}$, H. Sudarsana Rao $^{2}$, P. Suresh Praveen Kumar ${ }^{3}$
}

\author{
${ }^{1}$ Associate professor, Dept of Civil Engineering, KSRM College of Engineering-Kadapa, A.P. \\ ${ }^{2} I / C$ Vice chancellor and Professor of Civil Engineering, JNTUA, Ananthapuramu, A.P \\ ${ }^{3}$ Assistant Professor, Dept of Civil Engineering, KSRM College of Engineering-Kadapa, A.P
}

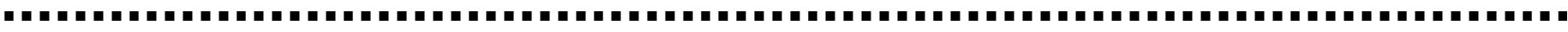

Abstract

The Present paper investigates the influence of ceramic waste aggregate properties on strength aspects of ceramic waste aggregate concrete. Ceramic waste aggregate concrete (CWAC) is prepared by replacing natural coarse aggregate with ceramic waste aggregate at 0, 20, 40, 60, 80 and 100\%. The behavior of ceramic waste aggregate concrete (CWAC) is studied in two states, fresh state and hardened state. In fresh state, workability studies are studied with slump cone test and compaction factor test and in hardened state, strength of the CWAC is studied with compression test and tensile strength by indirect method. Due to the influence of water absorption and external porcelain nature, composition of the ceramic waste aggregate, workability and strength of the ceramic waste aggregate concrete is declining gradually but its strength values are more than the targeted mean strength of M20 grade concrete even after replacing 100\% of natural coarse aggregate.
\end{abstract}

Keywords: Ceramic waste aggregate, Ceramic aggregate concrete, water absorption, Compressive strength, Tensile strength.

\section{INTRODUCTION:}

Concrete has become inevitable construction material in human life due to wide spread usage in modern construction and its properties like strength and durability. Concrete is a material synonyms with strength and longevity have emerged as the dominant construction material for the infrastructural needs in the present situation. Due to the vast usage of concrete in India, unavailability of quality concrete ingredients is observed in the nature. The continuous usage of natural resources and the consequent energy requirement for this processing has a serious economic impact. So, for future generation, concrete ingredients have to be left over by replacing the quantity of concrete ingredients.

Ceramic waste from ceramic industries is one of the serious problems of generating waste near by the industries. Ceramic industrial waste is used into production of new concrete by replacing natural coarse aggregate and fine aggregate at different levels. In INDIA it has been estimated that about $30 \%$ of the daily production of ceramic materials goes on waste during the manufacturing, transportation and usage. Recycling of ceramic waste is not practicing at present, however the ceramic waste is durable, hard and highly resistant to the biological, chemical and physical degradation forces. [1]. There is an interest mounting up to the handling of waste materials as different aggregates and significant research was performed on the use of many different materials as aggregate substitute such as ceramic waste and other industrial wastes. The waste aggregates can be used as well as in mortar and concrete. These waste materials can solve few problems like lack of aggregates in construction sites and environmental problems [2]. In India, ceramic production is 100 million ton per year and about 15$30 \%$ of ceramic waste is generating from the total production [3]. Nearly $30 \%$ of waste is generated during the manufacturing, transportation and usage of ceramic products [4]. Ceramic products are made from natural materials which contain high proportion of earth minerals, through a process of dehydration followed by controlled firing at temperatures of 1200 to $1290^{\circ} \mathrm{c}$ [5]. Based on the previous research, ceramic waste aggregate was durable, hard and highly resistant to chemical and physical degradation forces [6].The surface texture mineralogy affected the bond between ceramic waste aggregate and cement paste. Depreciation of strength was due to increase of stress levels on specimen at which micro cracking was begun for failure [7]. The strength of ceramic aggregate concrete with ceramic insulator scrap has decreased and it was $16 \%$ lower compressive strength and $11 \%$ lower split tensile strength than the conventional concrete for 28 days. The reason for decreased mode was due to smooth surface texture of ceramic aggregates and poor bonding properties of the matrix with aggregates [8]. Compressive strength and split tensile strengths were decreased when the percentage of replacement with ceramic waste aggregate increased due to the mechanical properties of ceramic waste aggregate [9]. The rate of decrease for compressive strength and split tensile strength of ceramic waste concrete was 3.8 and $18.2 \%$ [10]. The weakest results were obtained with brick ceramic as coarse aggregate in concrete composition and compressive strength was reduced to $38 \%$ with $100 \%$ replacement of coarse aggregate. Reduction behavior of compressive strength was due to angular shape of aggregate, which produced large amount of voids in the concrete section [11]. The compressive strength of ceramic waste 
aggregate concrete ranges from 15-30MPa and these values were lower than conventional concrete [12]. Crushed ceramic block was used as coarse recycled coarse aggregate in concrete composition, the compression resistance and modulus of elasticity were equal with natural coarse aggregate by replacing recycled aggregate at 10 and $20 \%$ but results were decreased when substitution of coarse aggregate was $40 \%$ [13]. Compressive and split tensile strengths of ceramic waste aggregate concrete were 13 and $31 \%$ lower than the conventional concrete due to higher water absorption and brittle nature of the ceramic waste aggregate [14].

\section{EXPERIMENTAL INVESTIGATION}

\section{Experimentation was performed for the conclusion}

\section{of following}

$>$ To study the basic physical and mechanical properties of ceramic waste aggregate

$>$ To Verify the condition of CWAC in fresh state

$>$ Behavior of ceramic waste aggregate under compression and indirect tension

$>$ Percentage loss of strength for ceramic waste aggregate concrete

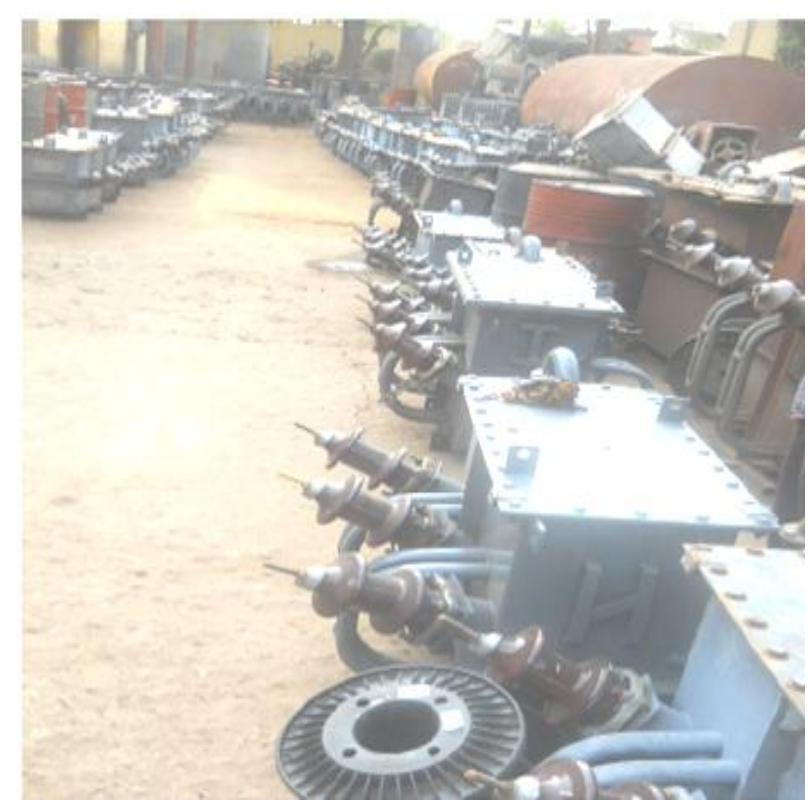

Fig-1 Usage of Ceramic bush into the transformers

\section{MATERIALS}

\subsection{Cement}

Ordinary Portland cement of 53 grade, conforming to IS12269-1987 has been procured for experimentation work. Specific gravity of cement was 3.05 and initial setting and final setting times were 80 and 280 minutes respectively.

\subsection{Fine aggregate}

Locally available "Penna river" sand has been used as fine aggregate in the experimental work and it was conformed to zone-II of Table 4 according to IS: 383-1970. Specific gravity of fine aggregate was found as 2.62 .

\subsection{Natural coarse aggregate}

Crushed granite aggregate available from local sources has been used in the experimental work and its specific gravity was 2.64

\subsection{Ceramic waste aggregate}

Ceramic waste has been collected from waste dump at "Shirdi Sai Electricals-Kadapa", A.P, (India). Ceramic bushes are used in manufacturing of transformers and crushing of waste ceramic bushes was carried out manually to make the required size of aggregate as 20 and $12.5 \mathrm{~mm}$. Figland fig 2 are representing the usage of ceramic bush into the manufacturing of transformers and the waste dump developed at ceramic industry. The properties of ceramic waste aggregate and comparison of properties with respect natural coarse aggregate are published in Table 1.

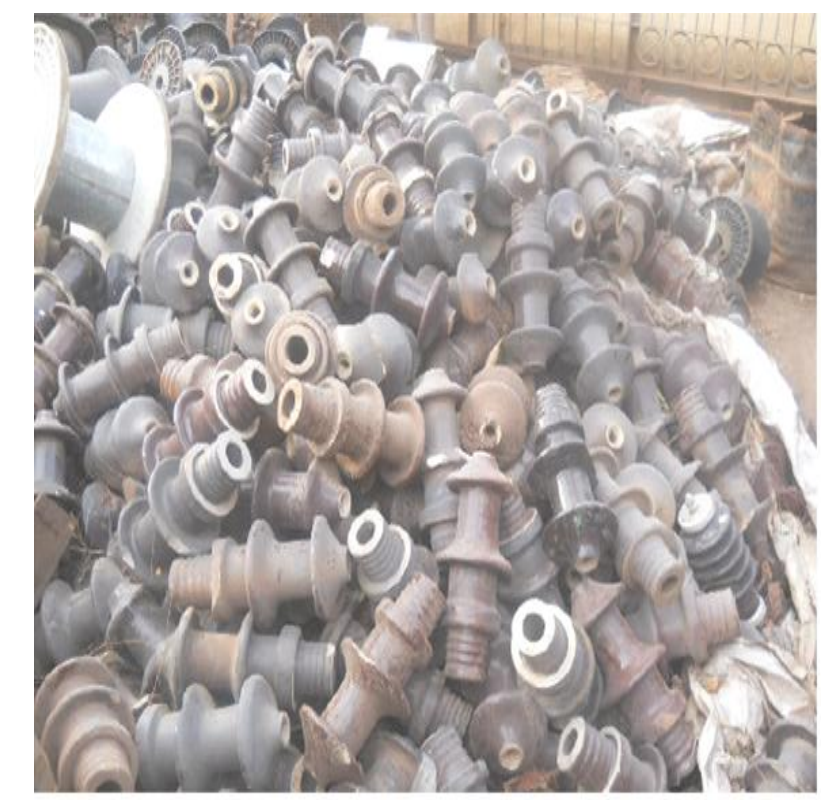

Fig-2 Ceramic waste dump 


\subsection{Water}

Locally available bore well water has been used for mixing and curing of concrete specimens and concluded that the water available from the local source was fit for usage.

\section{MIX PROPORTION}

Mix design was prepared for M20 grade concrete according to the IS: 10262-2009, its proportion was 0.48:1:1.53:2.88(W: C: FA: CA) by weight. For better workability of concrete,

Table-1 Comparison of coarse aggregate properties

\begin{tabular}{|c|l|c|c|c|c|}
\hline S.no & \multicolumn{1}{|c|}{ Property } & $\begin{array}{c}\text { Ceramic waste } \\
\text { Aggregate } \\
\text { (Insulator bush) }\end{array}$ & $\begin{array}{c}\text { Natural } \\
\text { aggregate } \\
\text { (Granite) }\end{array}$ & $\begin{array}{c}\text { \% Variation } \\
\text { With respect to } \\
\text { natural aggregate }\end{array}$ & $\begin{array}{c}\text { Permissible } \\
\text { limits }\end{array}$ \\
\hline 1 & Specific gravity & 2.50 & 2.64 & $-5.6 \%$ & $2.6-2.8$ \\
\hline 2 & Water absorption in \% & 0.18 & 0.10 & $+40 \%$ & $<0.5$ \\
\hline 3 & Impact value in \% & 22 & 18.6 & $+18.3 \%$ & $<30 \%$ \\
\hline 4 & Crushing value in \% & 20 & 15.3 & $+30.7 \%$ & $<30 \%$ \\
\hline 5 & Abrasion value in \% & 19 & 14.25 & $+33.33 \%$ & $<30 \%$ \\
\hline 6 & $\begin{array}{l}\text { Bulk Density in } \mathrm{kg} / \mathrm{m}^{3} \\
\text { Loose state } \\
\text { Dense state }\end{array}$ & 1069 & 1219 & $-12.3 \%$ & - \\
\hline
\end{tabular}

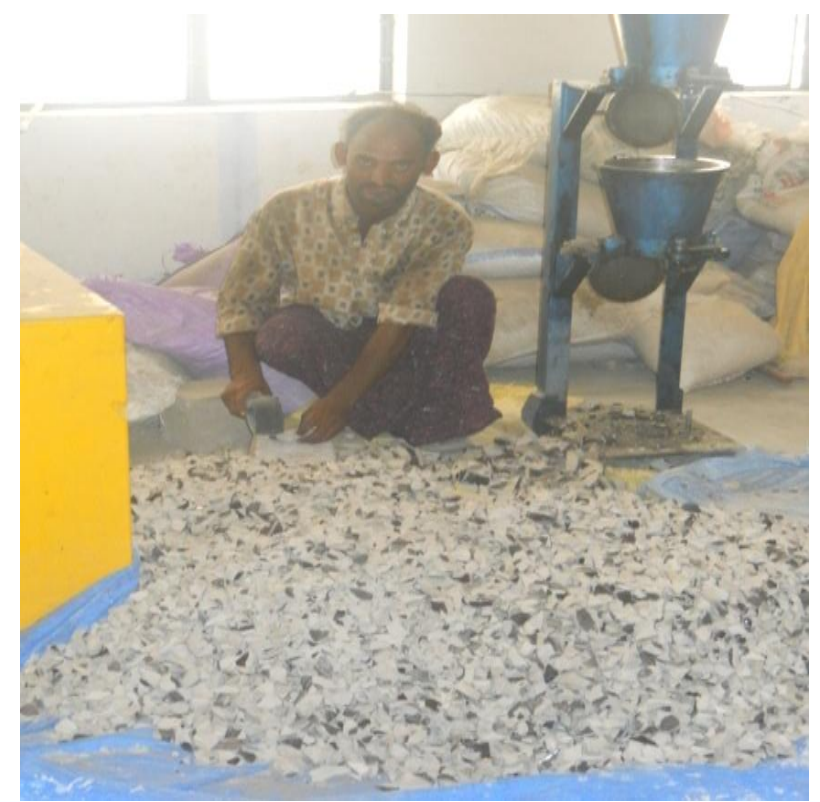

Fig-3 Manual crushing of CWA

graded aggregates were used in two fractions as $60 \%$ of 20 and $40 \%$ of $12.5 \mathrm{~mm}$ size of coarse aggregate in concrete composition. Natural coarse aggregate was replaced with crushed ceramic waste aggregate at $0,20,40,60,80$ and $100 \%$ in the concrete composition. With reference from the experimental results from Table 1, ceramic waste has low specific gravity, little higher water absorption and low

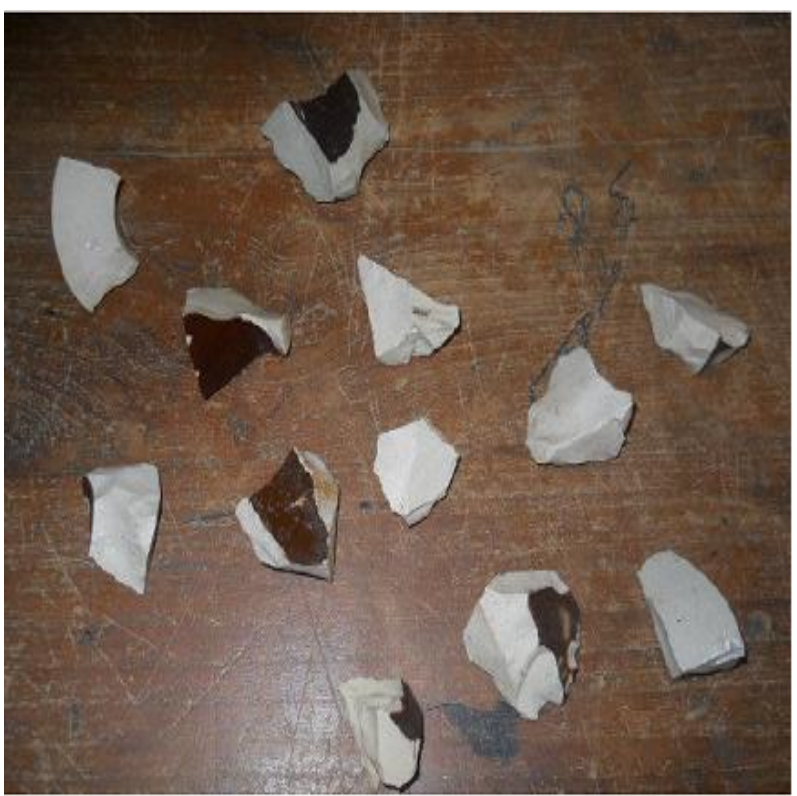

Fig-4 Required size of CWA

density. The properties of ceramic waste is well within the range according to the IS recommendations and fig 3 representing the ceramic waste aggregate after manual crushing and required size of CWA shown in Fig-4 . Table 2 , is representing the nomenclature, $\mathrm{R}$ stands for reference concrete and CWAC stands as ceramic waste aggregate concrete with appropriate replacement. 
Table-2 Quantities of concrete ingredients for the mix per cubic meter

\begin{tabular}{|c|c|c|c|c|c|c|c|c|}
\hline $\begin{array}{c}\text { S. } \\
\text { No }\end{array}$ & Nomenclature & $\begin{array}{c}\text { \% of } \\
\text { replacement } \\
\text { with } \\
\text { Ceramic } \\
\text { waste }\end{array}$ & $\begin{array}{c}\text { w/c } \\
\text { Ratio }\end{array}$ & $\begin{array}{c}\text { Cement } \\
\text { in kg/m }\end{array}$ & $\begin{array}{c}\text { Fine } \\
\text { aggregate } \\
\text { In kg }\end{array}$ & $\begin{array}{c}\text { Coarse } \\
\text { aggregate } \\
\text { In kg }\end{array}$ & $\begin{array}{c}\text { Ceramic } \\
\text { aggregate } \\
\text { In kg }\end{array}$ & $\begin{array}{c}\text { Water } \\
\text { In lit }\end{array}$ \\
\hline 1 & R & 0 & 0.48 & 383 & 586 & 1103 & 0 & 183.8 \\
\hline 2 & CWAC20 & 20 & 0.48 & 383 & 586 & 882 & 221 \\
\hline 3 & CWAC40 & 40 & 0.48 & 383 & 586 & 662 & 441 \\
\hline 4 & CWAC60 & 60 & 0.48 & 383 & 586 & 441 & 183.8 \\
\hline 5 & CWAC80 & 80 & 0.48 & 383 & 586 & 221 & 183 \\
\hline 6 & CWAC100 & 100 & 0.48 & 383 & 586 & 0 & 882 \\
\hline
\end{tabular}

\section{TEST PROGRAMME}

\subsection{Workability of CWAC}

\subsubsection{Slump value}

To study the behavior of ceramic aggregate concrete in fresh state, slump cone and compaction factor tests were performed. Slump test was carried out according to the IS 1199-1959. The subsidence of slump will depend on water content and the mixing time. If the mix is too wet, leads to

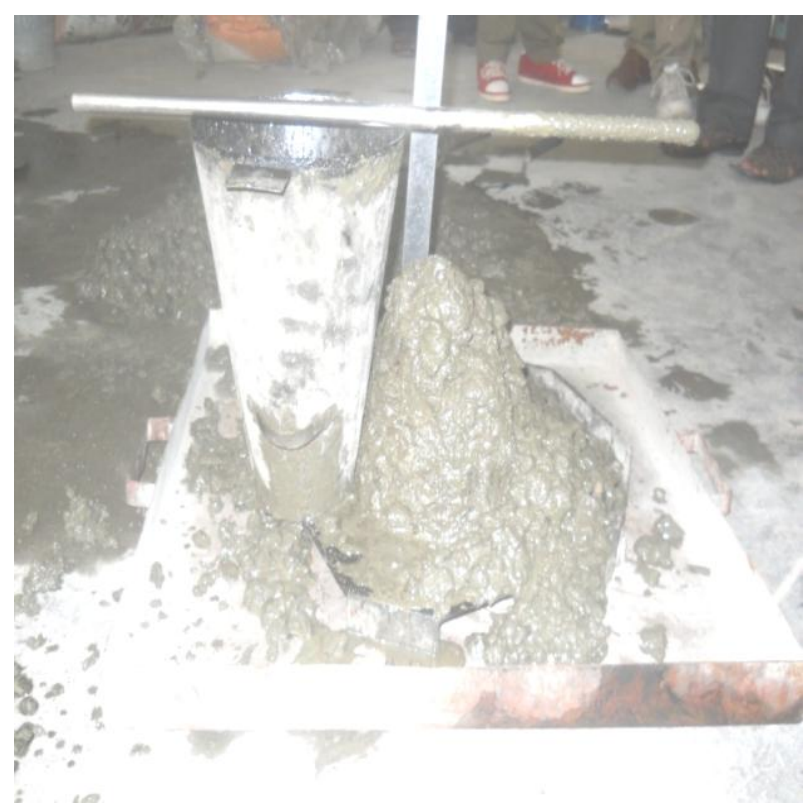

Fig-5: Measurement of slump fall.

\subsection{Compressive strength}

According to the IS 516-1959, Cube specimens were cast of size $150 \times 150 \times 150 \mathrm{~mm}$ and substituted natural coarse aggregate with ceramic waste aggregate. Mix design was prepared for M20 grade concrete and its targeted mean strength was $26.6 \mathrm{MPa}$, total 36 cube specimens were cast, collapse in the slump. Fig-5 is representing the measurement of slump fall.

\subsubsection{Compaction Factor}

Compaction factor test is more precise and sensitive than the slump test when recycled aggregates are proposed to use into the concrete composition. Fig-6 presenting the compaction factor of CWAC

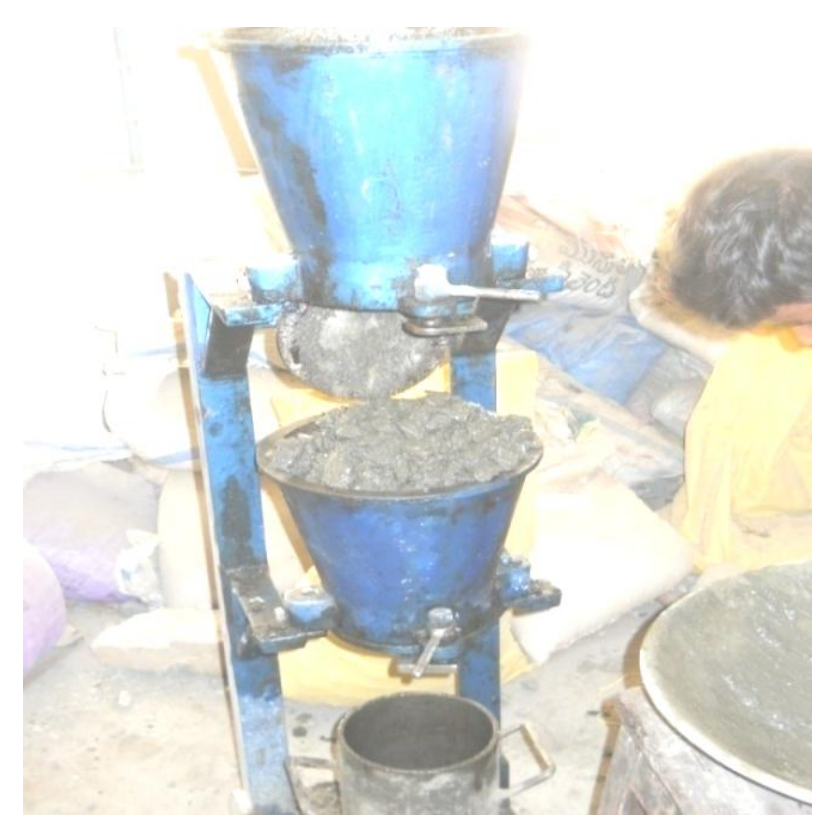

Fig-6 Compaction factor of CWAC

among these 6 specimens have been cast with natural coarse aggregate (local available "crushed-Granite") and rest of the samples were cast replacing natural coarse aggregate with waste ceramic aggregate in different percentages. 


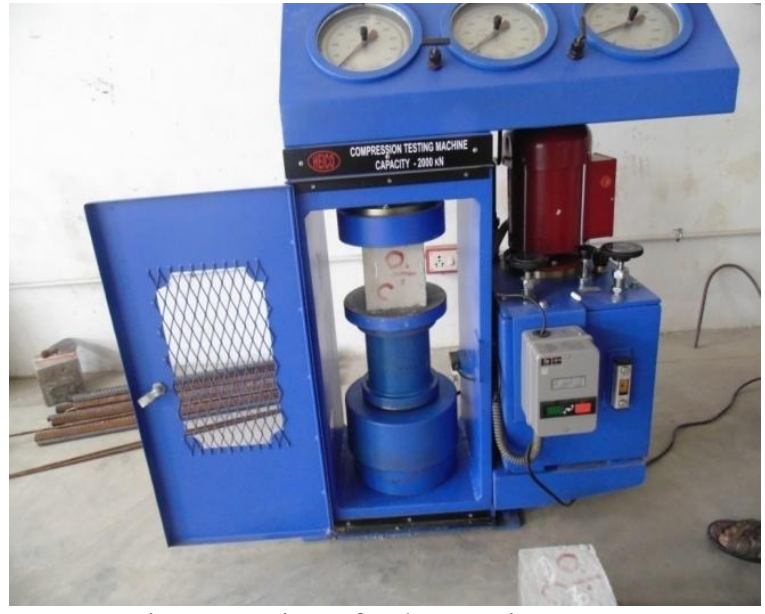

Fig-7: Testing of cube specimen

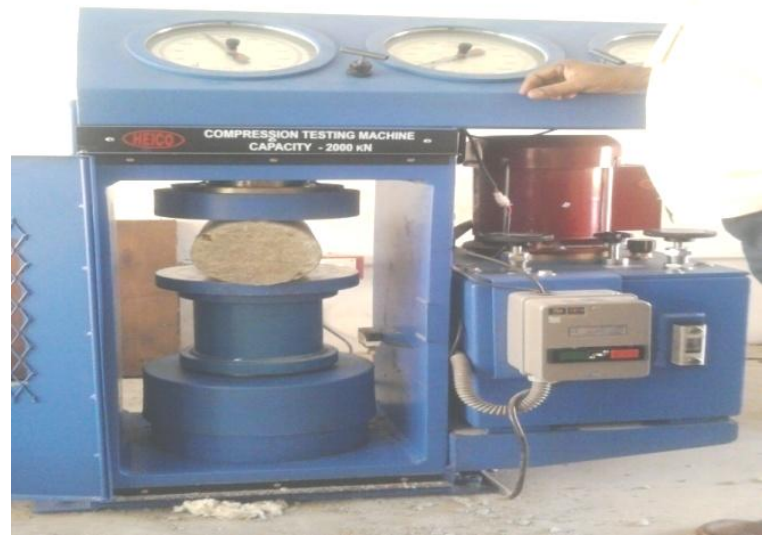

Fig-8 Testing of cylindrical specimen

\subsection{Split tensile strength}

It is difficult to apply uniaxial tension to a cylindrical specimen, hence, tensile strength is determined by indirect methods. To find the tensile strength of concrete, total 36 cylindrical specimens were cast according to the same specified materials, composition and proportion. The size of the cylindrical specimen was 150 × $300 \mathrm{~mm}$ and tested in diametrical position in compressive testing machine. Fig 7 and 8 are repressing the testing of cube and cylindrical specimens.

\section{RESULTS AND DISCUSSIONS}

\subsection{Workability of CWAC}

\subsubsection{Slump value}

Water absorption of ceramic waste aggregate and natural granite aggregate was recorded as 0.18 and $0.10 \%$ respectively. A little variation was observed between these aggregates. Due to higher water absorption and irregular shape of ceramic waste aggregate, the cohesiveness of ceramic waste aggregate in concrete composition has been dipping when the replacement was increased. Workability of ceramic aggregate concrete decreases as the percentage of replacement of ceramic waste aggregate increased.

Table3: Workability of CWAC

\begin{tabular}{|c|c|c|c|c|}
\hline $\begin{array}{c}\text { S. } \\
\text { No }\end{array}$ & Nomenclature & $\begin{array}{c}\text { Percentage replacement of } \\
\text { natural coarse aggregate by } \\
\text { ceramic waste aggregate }\end{array}$ & $\begin{array}{c}\text { Slump value in } \\
\text { mm }\end{array}$ & $\begin{array}{c}\text { Compaction } \\
\text { factor }\end{array}$ \\
\hline 1 & R & 0 & 120 & 0.87 \\
\hline 2 & CWAC20 & 20 & 110 & 0.85 \\
\hline 3 & CWAC40 & 40 & 110 & 0.85 \\
\hline 4 & CWAC60 & 60 & 100 & 0.84 \\
\hline 5 & CWAC80 & 100 & 100 & 0.83 \\
\hline 6 & CWAC100 & 90 & 0.83 \\
\hline
\end{tabular}

\subsubsection{Compaction Factor}

Workability of ceramic waste aggregate concrete was decreases with increase of percentage replacement of natural coarse aggregate with ceramic waste aggregate. This is mainly due to the higher water absorption of ceramic waste aggregate leading to lesser water content in the mix. This fact is revealed by both slump and compaction factor tests. Another reason was texture of the ceramic waste aggregate. It has smooth texture on surface of the aggregate but during the crushing of ceramic waste, pore structure wide opened and porcelain surface was fade out. 


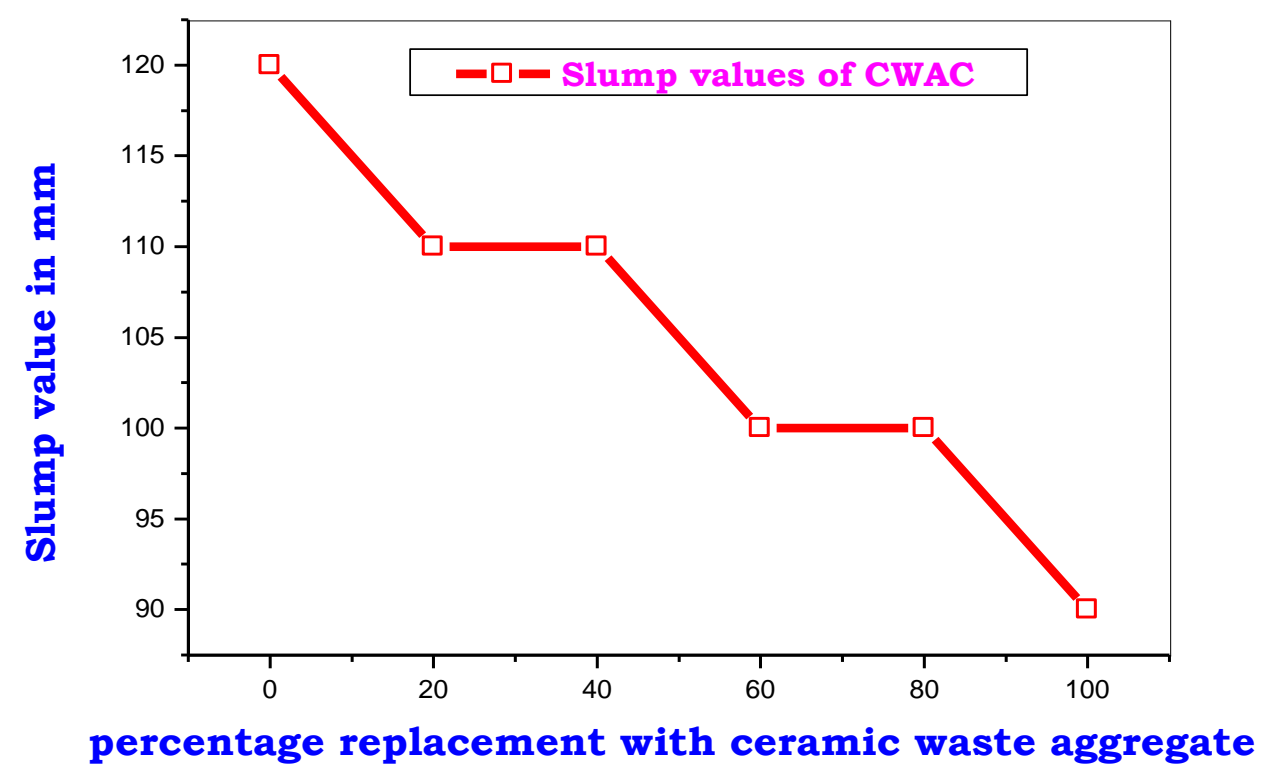

Fig-9 Workability of CWAC with slump cone

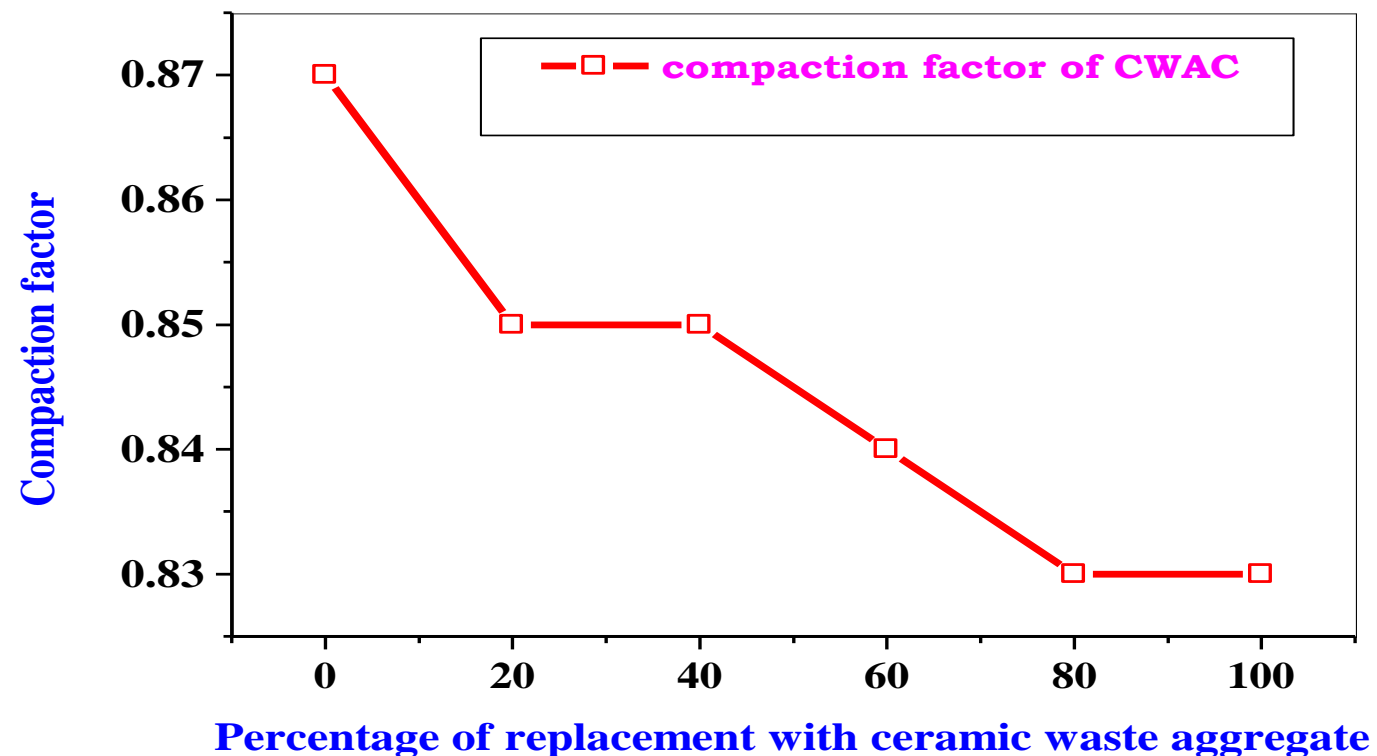

\subsection{Compressive strength}

Aggregate characteristics have a significant effect on the behavior of fresh and hardened concrete. Characteristics of concrete are changing continuously as a function of aggregate properties. Compressive strength of the ceramic aggregate concrete was influenced by the properties of ceramic waste aggregate and bonding between the cement paste and aggregate. Ceramic aggregate concrete has weak

\section{with Compaction factor}

interfacial transition zone (ITZ), because of improper bonding between the cement paste and ceramic coarse aggregate due to its porcelain surface. Strength of ceramic waste aggregate concrete followed declining trend due to higher water absorption, porcelain texture and volume fraction of ceramic waste aggregate in the concrete composition. 
Table 4: Compressive strength of cube specimen for ceramic waste aggregate concrete

\begin{tabular}{|c|l|c|c|c|}
\hline S. No. & Nomenclature & $\begin{array}{c}\text { \% of Replacement of } \\
\text { ceramic waste aggregate }\end{array}$ & $\begin{array}{c}\text { Average 7days } \\
\text { strength in MPa }\end{array}$ & $\begin{array}{c}\text { Average 28days } \\
\text { strength in MPa }\end{array}$ \\
\hline 1 & R & 0 & 29.33 & 37.03 \\
\hline 2 & CWAC20 & 20 & 27.41 & 36.60 \\
\hline 3 & CWAC40 & 40 & 24.30 & 34.96 \\
\hline 4 & CWAC60 & 60 & 23.41 & 34.67 \\
\hline 5 & CWAC80 & 80 & 22.81 & 34.33 \\
\hline 6 & CWAC100 & 100 & 21.33 & 32.15 \\
\hline
\end{tabular}

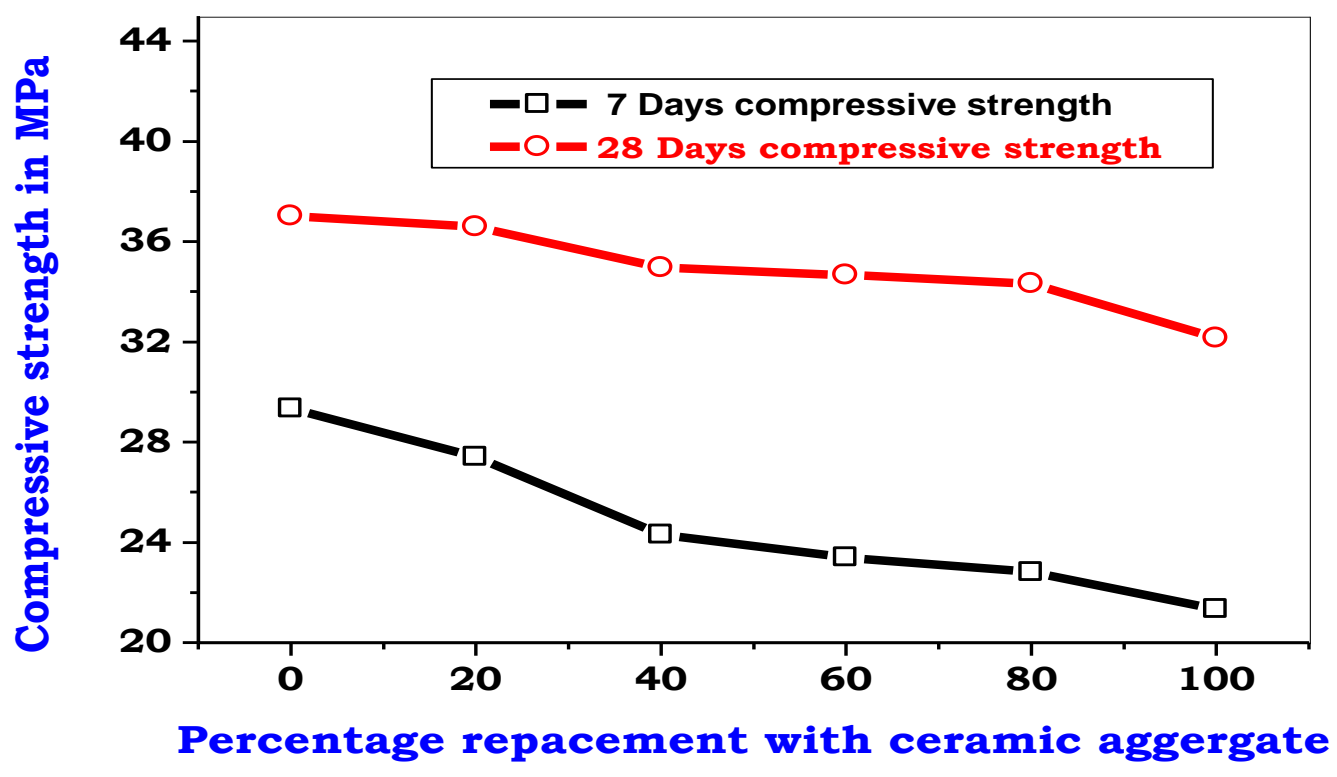

Fig11: Compressive strength of CWAC

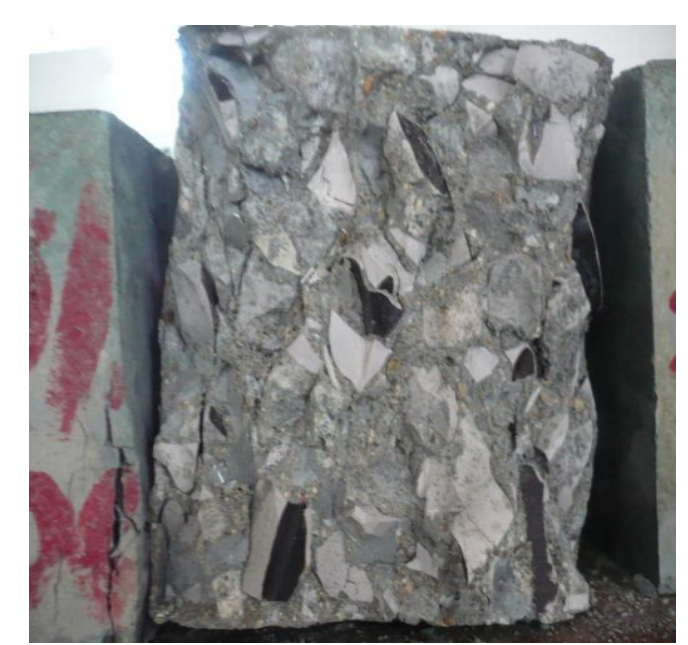

Fig-12: Interfacial transition zone failure of CWAC after testing 
Based on the experimental results from Table 4, reference concrete exhibited 7 days compressive strength of $29.33 \mathrm{MPa}$ and it was decreased to $21.33 \mathrm{MPa}$ with $100 \%$ replacement. For 28 days compressive strength, reference concrete strength had $37.03 \mathrm{MPa}$ and slowly decreased to $32.15 \mathrm{MPa}$ after full replacement. This value was much higher than the targeted mean strength of $26.6 \mathrm{MPa}$. Finally, due to above said reasons, compressive strength of ceramic waste aggregate concrete gradually decreased with respect to reference concrete. Fig 11 and 12 are representing the graphical presentation of compressive strengths and ceramic waste aggregate concrete specimen after crushing. It is clearly observed that weak interfacial transition zone from fig-12.

\subsection{Split tensile strength.}

Ceramic waste aggregate has more surface area due to irregular shape, the required quantity of cement paste is more for proper bonding but ratio of cement paste to the aggregate maintained constant throughout the compositions. Due to this reason, poor bonding observed between the cement paste and ceramic waste aggregate. Hence, interfacial transition zone of ceramic waste aggregate concrete was weaker than the reference concrete and brittle nature of the ceramic aggregate also influence the split tensile strength values. Observed in 28 days strength also, for reference concrete (R) and CWAC 100, split tensile strength values were 3.54 and $2.44 \mathrm{MPa}$ respectively. The same reasons which influence the compressive strength will also influence the split tensile strength of ceramic waste aggregate concrete. A clear failure of interfacial transition zone is presented in Fig 14.

Table 5: Split tensile strength of cylindrical ceramic waste aggregate concrete specimens

\begin{tabular}{|c|l|c|c|c|}
\hline S. No. & Nomenclature & $\begin{array}{c}\text { \% of replacement } \\
\text { of ceramic waste } \\
\text { aggregate }\end{array}$ & $\begin{array}{c}\text { Average 7 days } \\
\text { strength } \\
\text { (MPa) }\end{array}$ & $\begin{array}{c}\text { Average 28 days } \\
\text { strength (MPa) }\end{array}$ \\
\hline 1 & \multicolumn{1}{|c|}{$\mathrm{R}$} & 0 & 2.67 & 3.54 \\
\hline 2 & CWAC20 & 20 & 2.60 & 3.32 \\
\hline 3 & CWAC40 & 40 & 2.42 & 2.90 \\
\hline 4 & CWAC60 & 60 & 2.26 & 2.74 \\
\hline 5 & CWAC80 & 80 & 2.17 & 2.69 \\
\hline 6 & CWAC100 & 100 & 2.05 & 2.44 \\
\hline
\end{tabular}

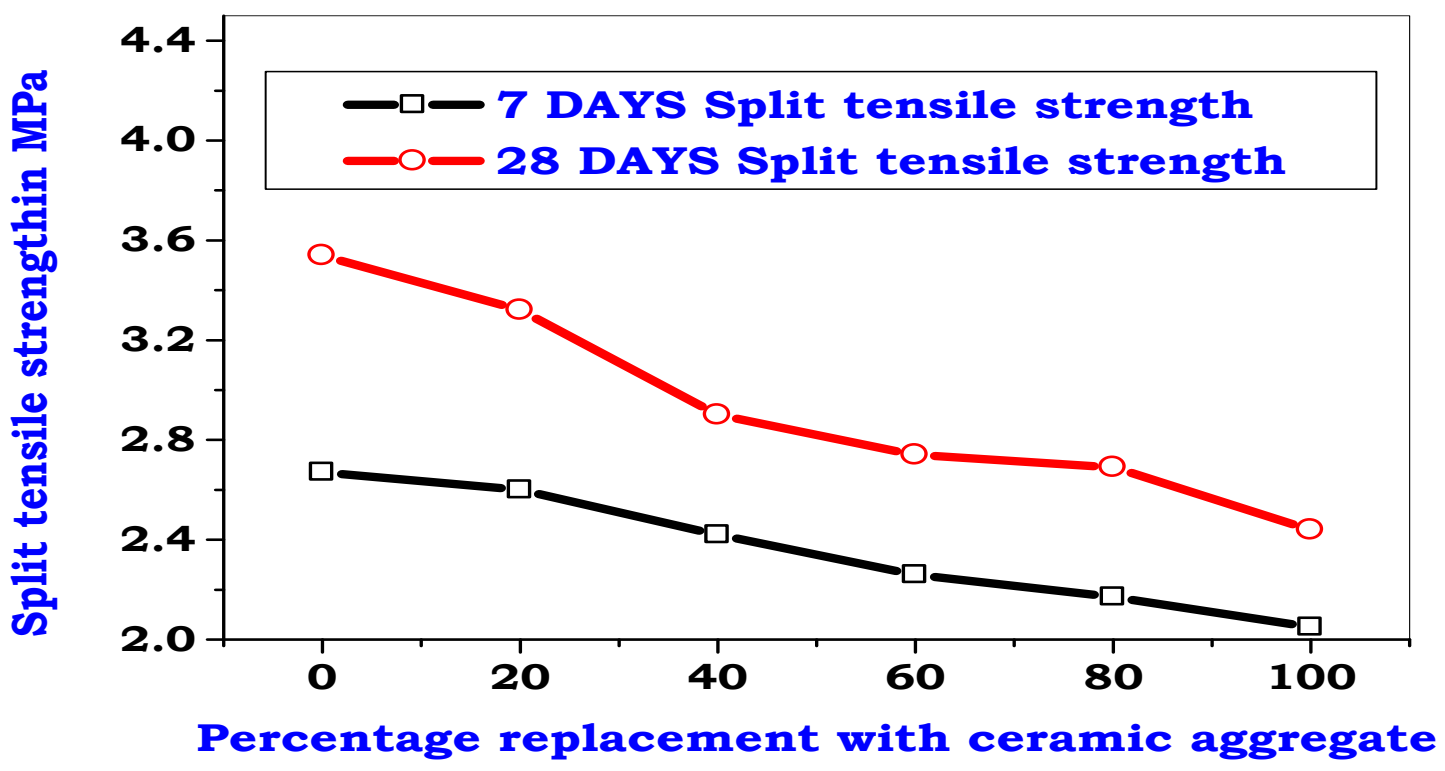

Fig-13: Split tensile strength of CWAC 


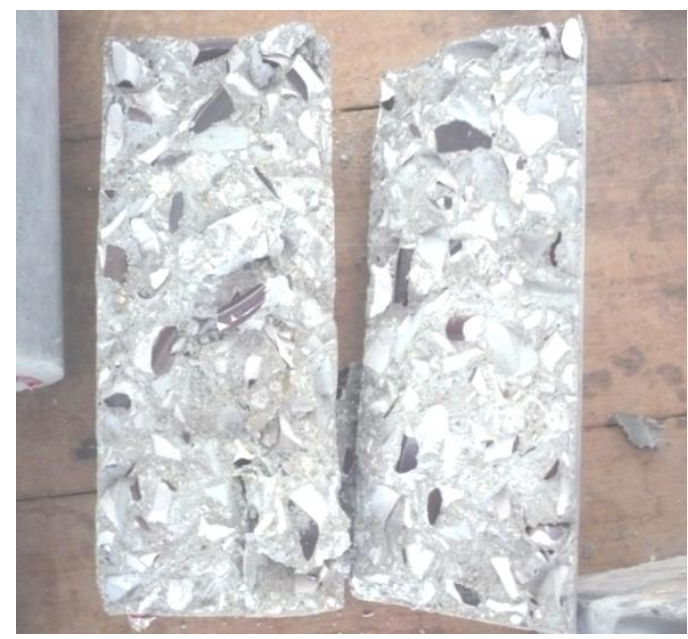

Fig14: Cylindrical specimen after testing

\section{CONCLUSIONS}

1. Based on the results of this investigation, it is concluded that ceramic waste aggregate has the potential to replace natural coarse aggregate in concrete as its physical properties are well within the range specified by IS: 383-1970. Hence the ceramic waste aggregate can be safely used in the concrete composition.

2. Water absorption of ceramic waste aggregate is slightly higher than of natural coarse aggregate due to

i) Higher surface area of irregularly shaped ceramic waste aggregate.

ii) Pore size expansion of ceramic waste aggregate during crushing process.

iii) Higher clay content in ceramic waste aggregate, which was fired at control temperature of 1200 to $1290^{\circ} \mathrm{C}$.

iv) Cracks formed on the surface of ceramic waste aggregate during crushing and chiseling.

3. Mechanical properties such as Impact value, Crushing Value and Abrasion value of ceramic waste aggregate are slightly higher than those for natural coarse aggregate. However all values are less than $30 \%$, hence ceramic waste aggregate can be safely used in concrete composition as alternative material for coarse aggregate.

4. Workability of ceramic waste aggregate concrete decreases with increase of percentage replacement of natural coarse aggregate with ceramic waste aggregate. This is mainly due to the higher water absorption of ceramic waste aggregate leading to lesser water content in the mix. This fact is revealed by both slump and compaction factor tests.

5. Compressive strength of ceramic waste aggregate concrete decreases with the increase of ceramic waste aggregate in composition. Even at 100\% replacement, compressive strength of ceramic waste aggregate concrete is $32.15 \mathrm{MPa}$. This is more than the target mean strength of M20 grade concrete. Hence it is concluded that ceramic waste aggregate concrete with $100 \%$ replacement can be used as M20 grade concrete. Up to $40 \%$ replacement, the reduction in compressive strength is $5.6 \%$, which is marginal. Hence it is recommended that $40 \%$ of replacement can be safely used in concrete composition without considerable loss of compressive strength.

6. The split tensile strength of ceramic waste aggregate concrete decreases with increase of replacement level. However the decrease is only $6.2 \%$ up to $20 \%$ replacement, which is marginal. Hence it is recommended that $20 \%$ replacement can be safely used in the M20 grade concrete from tensile strength consideration.

\section{ACKNOWLEDGEMENTS}

The authors acknowledge the support of Management, Director and Principal of KSRM College of Engineering, Kadapa and Shri Shirdi Sai Elecricals-Kadapa.

\section{REFERENCES}

[1] Khaloo, A.R., "Crushed tile coarse aggregate concrete" Cement, Concrete and Aggregate (ASTM Journal), Vol 7, issue 2, pp119-125, 1995.

[2] de Britto and Saikia., "Recycled Aggregate in concrete" Green Energy and Technology, DOI 10.1007/978-1-44714540, O_2, Springer Verlag, 2013.

[3] Amit kumar Raval., Indrajit patel and Jayesh kumar pitroda., " Re-use of ceramic industry wastes for the elaboration of eco efficient concrete", International Journal of Advanced Engineering Research and studies, Vol 2, Issue 3, pp103-105, 2013.

[4] Santhamarai, R.M., Devadas Manoharan, .P and Gopindh, D., "Concrete made from ceramic waste: Durability properties", Construction and Building Materials, Vol 25, pp2413-2419, 2011.

[5] Medina, C., Sanchez de Rojas and Frias, M.I, "Reuse of sanitary ceramic wastes as coarse aggregate in eco- efficient concretes", Cement and Concrete Composites, Vol 34, pp48-54, 2012. 
[6] Siddes, H, "Experimental studies effect of fine ceramic aggregate on the strength properties of concrete", International journal of advances in Engineering, Science and Technology, Vol 1, Isuue 1, pp 71-76, 2011.

[7] Mohd Mustafa Al Bakri. A, Norazian M.N, Kamaruddin, H. and Che Mod Ruzaidi, G, "The potential of recycled ceramic waste as coarse aggregates for concrete", Malaysian Universities Conferences on Engineering and Technology, March 8-10, 2008.

[8] Sekar, T., Ganesan, N and Nampoothiri, NVN., "Strength Characteristics on Utilization of waste Materials as Coarse Aggregate in Concrete", International Journal of Engineering Science and Technology (IJEST), Vol 3, pp5436-5440, 2011.

[9] Correia, J.R., De Brito, J., and Pereira, A.S., "Effects on concrete durability of using recycled ceramic aggregates", Materials and Structures, Vol 39, pp 169-177. 2006.

[10] Senthamarai, A.R., and Devadas Manoharan, "Concrete with ceramic waste aggregate", Cement \& Concrete Composites, Vol 27, pp 910-913. 2005.

[11] Antonio Eduardo Bezerra Cabral., Valdir Schalch., Denise Carpena Coitinho Dal Molin, "Mechanical properties modeling of recycled aggregate concrete", Construction and Building Materials, Vol 24, pp521-530. 2010.

[12] Mohd Mustafa Al Bakri, A., Kamarudin Hussin, Che Mohd Ruzaidi, Shamsul Baharin , Rozaimah Ramly, and Nur Khairiatun Nisa, "Concrete with ceramic waste and quarry dust aggregate", 5th Annual conference management in construction research association, 2005.

[13] J. Marcio, Estefano, de oliveira, Cassia Silveira de Assis, and Antonia Wanderley Terni, "Study on Compressed stress, Water absorption and Modulus of elasticity of produced concrete made by recycled aggregate", International RILEM conference on the use of Recycled Materials in buildings and structures, Barcelona, Spain, 2004.

[14] Sudarsana Rao hunchate, Giridhar valikala, and Vaishali.G.Ghorphade, "Influence of water bsorption of the ceramic aggregate on strength properties of ceramic aggregate concrete", International journal of Innovative Research In science, Engineering and Technology, Vol 2, ISSUE 11, PP 6329-6335, 2013. 